\title{
Rummaging Through the Ashes: 9/11 American Poetry and the Transcultural Counterwitness
}

\section{Matthew Moran}

\section{(2) OpenEdition \\ Journals}

Electronic version

URL: https://journals.openedition.org/ejas/16018

DOI: 10.4000/ejas.16018

ISSN: 1991-9336

Publisher

European Association for American Studies

\section{Electronic reference}

Matthew Moran, "Rummaging Through the Ashes: 9/11 American Poetry and the Transcultural Counterwitness", European journal of American studies [Online], 15-2 | 2020, Online since 30 June 2020, connection on 08 July 2021. URL: http://journals.openedition.org/ejas/16018 ; DOI: https://doi.org/ 10.4000/ejas. 16018

This text was automatically generated on 8 July 2021.

Creative Commons License 


\title{
Rummaging Through the Ashes: 9/11 American Poetry and the Transcultural Counterwitness
}

\author{
Matthew Moran
}

\section{Introduction}

1 In the wake of $9 / 11$, poetry proved an important medium for national expression. A year after the attacks, over 25,000 poems had been published on poems.com alone (Metres), and a year later, in The Best American Poetry 2003, edited by Yusef Komunyakaa, almost a fifth of the poems addressed the terrorist attacks or New York City (Keniston 659). In addition to print and virtual sites, poems were produced on nonconventional sites, such as the walls of Union Square and the sides of buildings (Gray 265). Poetry was such an important outlet of expression that one New York Fire Department chief pleaded with New Yorkers to give food, flowers and blankets, but refrain from publishing poems (Johnson \& Merians ix).

2 Although studies of $9 / 11$ poetry have been extensive, this essay returns to the attacks of September 11th to explore how two 9/11 poems, "First Writing Since (Poem on Crisis of Terror)" by Suheir Hammad and "Alabanza: In Praise of the Local 100" by Martin Espada, challenge the pervasive patriotism presented in mainstream journalism through acts of transcultural counterwitnessing. By drawing on current definitions of testimonial witnessing and public circulation, this study acknowledges the value of transcultural voices in America's ongoing battle with identity politics, post-9/11. Through its investigation of Hammad and Espada's writings, I address the following questions: How do Suheir Hammad and Martin Espada's 9/11 poems oppose, and engage with, the pervasive patriotism presented in mainstream journalism? What is the value of transcultural poetry when confronting the factors that contribute to extreme violence? This study begins by briefly defining the key term "transcultural 
counterwitness" before turning to its analysis of Suheir Hammad and Martin Espada's poems.

\section{Defining Transcultural Counterwitnessing}

3 To explore the notion of "transcultural counterwitnessing," it is important to first define the term and its role in my analysis. The modifier "transcultural" assumes two distinct purposes: first, it illuminates how remembrance is understood beyond national or local frameworks; and second, it reconsiders who has the right to bear national and cultural memory (Rothberg, "A Dialogue on the Ethics and Politics" 31). The transcultural figure occupies an important dialogical space and serves to draw attention to complex interactions between peoples, cultures, and patterns of belonging in a globalized world. It has been argued that the 9/11 attacks encouraged a conservative shift in American definitions of national identity and communal belonging (Zamorano Leena 4). Transcultural figures challenge such traditional understandings of national culture by providing access to diverse perspectives, and the various cultural and social backgrounds which contribute to broader understandings of national identity (Zomorano Llena, Hansen, and Gilsenan Nordin ix-xi).

The notion of "counterwitness" draws on research from the fields of witness testimony and the public sphere. In The Moral Witness, Carolyn Dean defines the "counterwitness" as a "marginal cultural figure [who] emerges as a symbol of frustration with uneven global justice and the strain injustice places on the governance systems it has created and sustained" (138). For Dean, this includes third parties, such as humanitarian workers, journalists, and onlookers, who were not present during the violence but "supplement the testimonial roles of witnesses" (Dean 137).

5 Another contribution to the notion of the counterwitness comes from Michael Rothberg, who bases his thinking on Jürgen Habermas' and Michael Warner's concepts of the public and counterpublic spheres. According to Habermas, publics are spaces of interaction and circulation, which are distinct from the state and can be critical of it and are necessary for a functional democracy (Fraser 57). Publics are formed and accessed by language and forged between strangers (Warner 85). Counterwitnessing depends on creating alternative spaces within the public sphere where dominant discourses can be challenged. These counterpublics emerge from "a conflictual relation to the dominant public" (Warner 85). Counterpublics allow citizens to participate in the transformation of culture by pursuing new modes of expression and challenging public testimony (Warner 88; Gustafson 466). Poetry is one of the counterdiscourses that goes into the creation of counterpublics, and it poses a challenge to mainstream journalism and conservative political rhetoric. ${ }^{1}$

6 In the case of $9 / 11$, mainstream news coverage served as the primary means of witnessing the attacks for most Americans (Anker 23; Zelizer and Allan 7), with television being most prominent medium (Anker 23). In years following the attacks, the American public witnessed a surge of patriotic expression in mainstream journalism (Li and Brewer 728). For example, television coverage from providers such as Fox News and CNN, participated in countless reminders of nationalism. ${ }^{2}$ Reporters wore red, white, and blue ribbons, and segments were often adorned with logos of the American flag or had stars-and-stripes backgrounds (Wasibord 206). Broadcasters, such CBS anchorperson Dan Rather, publicly vowed to "line up" for the president and the 
country (Zelizer and Allan 5). This concept of "patriotic journalism" was most directly addressed by Fox Senior Vice President John Moody when he asserted that his news company's mantra "be accurate, be fair, be American" was important post-9/11 because it showed that journalism was not "uncomfortable embracing a good-versus-evil canvas" (Rutenberg).

7 This is not to suggest that mainstream journalism failed to engage in discussions of American pluralism. For example, The New York Times' moving tribute "Portraits of Grief" ${ }^{3}$ elegized the lives of Americans of various ethnic and national backgrounds, while networks like PBS ran specials such as "American Muslim Community Since September 11,"4 acknowledging the difficulties for Arab-American and communities of color, following the attacks. However, many studies have observed how mainstream journalism reinforced us-vs.-them political rhetoric and drew on Arab stereotypes to stoke public fear (Powell 92; Waisbord 205; Gershkoff and Kushner 526). For example, a study conducted by Kathleen Hall Jamieson and Paul Waldman describes how the mainstream coverage of 9/11 favored compelling narratives at the expense of accuracy which, in turn, greatly influenced how the general public viewed the attacks and Arabs (xii).

But Arab Americans were not the only targets of mainstream coverage. In her study The Criminalization of Immigration: The Post 9/11 Moral Panic, critic Samantha Hauptman describes how after $9 / 11$ mainstream journalism increased its coverage of news which linked migrant groups to criminality (Hauptman 126-127). In doing so, mainstream journalism establishes a climate of fear that associates immigrants and non-citizens with recurring social issues such as crime, national security, and terrorism (Hauptman 141). ${ }^{5}$ The overwhelming pro-government bias and anti-outsider sentiment in media narratives played a critical role in stoking public support for the US government's War on Terror (Bird 148; Gershkoff and Kushner 528). By framing the attacks through "the nation at risk" narrative, mainstream media "offered an opportunity to position patriotic identity by articulating the Other" (Waisbord 205). I call this us-vs.-them political frame "pervasive patriotism."

Because pervasive patriotism had such a significant impact on public opinion, poetry offered important possibilities for articulating counter-discourses. Suheir Hammad and Martin Espada counterwitness pervasive patriotism through their representations of the "intersections, overlaps, and tensions between disparate histories" (Rothberg, "Writing Ruins" 102). Multidirectional remembrances allow writers "to think of the public sphere as a malleable discursive space in which groups do not simply articulate established positions but actually come into being through their dialogical interactions with others" (Rothberg, Multidirectional Memory 13). There were many interesting poetic responses to 9/11 such as Lucille Clifton's "Tuesday 9/11/01" and Galway Kinnell's "When the Tower Fell." But such accounts address the trauma from nativist viewpoints. Transcultural poetics are more elastic in their ability to showcase the collision of intercultural relationships through their blurring of national labels and resistance to nativist views (Ramazani 14, 24).

Born in Lebanon, Suheir Hammad is the daughter of Palestinian refugees who migrated to Brooklyn when Hammad was five. Much of her writing invests in migrant perspectives to counter nativist American ones (Knopf-Newman 74). Hammad found that poetry provided an outlet to fight against anti-Arab sentiment in the United States, rebuking what Edward Said labelled the "essential terrorist" stereotype (Harb 
92). But Hammad does not write on behalf of Arabs alone: "First Writing Since" and her subsequent poetry confirm her agenda to provide a voice to her "Puerto Rican and Haitian and Italian and Jewish neighbors" (Knopf-Newman 79). While Suheir Hammad's poem focuses on effects of pervasive narratives on Arab-Americans, Martin Espada's broadens the conversations to demonstrates how such narratives impact migrants of color.

11 Martin Espada is a Brooklyn-based poet, born in 1957 and raised in the southwest borough of New York City in a Jewish-Puerto Rican household. Son of photojournalist/ activist Frank Espada, Martin Espada entered the world of activism from youth and found poetry a useful form to champion the struggles of American migrants. With "Alabanza," Espada saw an opportunity to counter rituals of patriotism and confront the dehumanization of immigrants (O'Conner). Hammad and Espada's emphases on global injustice draw attention to how an understanding of our world "is organized by political choices, rather than it being the result of a convenient Darwinist fatalism over which we have no control" (Roberts 11). ${ }^{6}$ Their attention to factors, such as mass migration, that contribute to violence underscores the value of transcultural counterwitnessing in multicultural societies like the United States. Both poets are deeply affected by the attacks and invest in communicating their confusion, despair, and loss. Their ethnicity and outsider status afford them a vantage point to counter patriotic rhetoric and enable dialogues on global injustice and violence often neglected in pervasive patriotism.

\section{Abstract Realities in Suhier Hammad's "First Writing Since"}

Suheir Hammad's "First Writing Since (Poem on Crisis of Terror)" was written just weeks after the attacks. Hammad emailed her poem to around 50 of her closest friends who then circulated it via the Internet (Hopkinson). Within months, the poem was available on more than 150 websites and received widespread attention following her performance on HBO's Def Comedy Jam (Rothberg, "Seeing Terror, Feeling Art" 135). The poem is prose-like in form, consisting of seven sections of various lengths and perspectives, and it reads like a diary. The poem's impact has been attributed to its performative elements, specifically its use of multiple voices and identities. ${ }^{7}$ These voices provide a multiplicity of perspectives, which are essential for the poem's thematic and formal purposes. Michael Rothberg, whose work has inspired this essay, has praised Hammad's poem for its treatment of private and public trauma. ${ }^{8} \mathrm{My}$ analysis will shift the focus to how the poem counterwitnesses the source and location of global violence.

The poem dramatizes a vast array of voices, ranging from the elegiac, humorous and hostile, to illustrate the fractured collective of the American people. For example, the "thank yous" of the second section draw attention to everyday stories of survival. The poem's subtle, anecdotal humor sheds light on the unexpected reasons for survival: some people survive through luck, procrastination, and even food poisoning. The third section, meanwhile, stages the more disturbing realties of $9 / 11$. Here, the poem's narration fluctuates between the singular and collective "i" through its dramatization of families searching for loved ones. The poem's use of the inclusive "we," and the linguistic echoes of the infamous "Amber Alerts" of the late 1990's, " emphasize the 
sense of despair and ill-founded hope invested in rescue and search missions at Ground Zero. As the section closes, its perspectival shift from the "we" to "i" reimagines the relationship between collective and individual mourning through its intense emotional buildup. The repetitive " $\mathrm{i}$ am looking for" (Hammad) intensifies the drama and connects the human and moral collateral damage. But perhaps the most imperative performance within the poem is that of an Arab, female other. For the remainder of this discussion, I will turn my attention to this performance and its role in counterwitnessing the attacks.

Hammad situates her Arab, female, other "i" between two cultures, the American and the Palestinian. The intentional omission of capitalization raises suspicion about claims of cultural identification and recognition. Although her use of " $i$ " demonstrates the heightened self-referentiality and self-reflexivity common to the first-person speaker of traditional lyrical poetry, the lack of capitalization evokes a sense of psychological displacement from her surroundings. ${ }^{10}$ The opening section of the poem, for example, illustrates the sense of fear and disassociation experienced by her Arab-American speaker through a series of random, interweaving meditations. Here, the performing "i" unites with, and breaks apart from, her audience through her confrontation with trauma: "there have been no words. / i have not written one word/ no poetry in the ashes south of canal street" (Hammad). From its outset, the speaker ensures the reader that she belongs to the greater American collective: she is a grieving citizen and a worried sibling. These feelings are short lived, however, as the speaker is forced to abandon her collective role to confront the immediate, inherited consequences of racialization:

fire in the city air and i feared for my sister's life in a way never

before, and then, and now, i fear for the rest of us.

first, please god, let it be a mistake, the pilot's heart failed, the plane's engine died.

then please god, let it be a nightmare, wake me now.

please god, after the second plane, please, don't let it be anyone

who looks like my brothers. (Hammad)

15 As the series of anaphoric "please gods" intensifies, the poem replaces the desolate mood of the opening with one of complete dread, as fears of citizen retaliation overtake the urge to participate in the larger experience of collective mourning. The fear felt for her sister results not from the death and debris at Ground Zero, but from more "abstract" uncertainties beyond the attack zone. Although the speaker is a victim of terror, like all other Americans, the speaker has difficulty articulating her Americanness, and instead refers to herself "as a woman, as a palestinian, as a broken human being" (Hammad). Her response echoes the Du Boisian notion of double consciousness, ${ }^{11}$ as she experiences herself as separated entities, rather than an autonomous whole, forcing the speaker into an either/or imperative of siding with her American or Palestinian identity.

But perhaps the most powerful performance of the citizen/other binary comes in section four. Here, the poem illustrates antithetical responses within the US political and cultural terrain and further complicates the inclusive/exclusive dynamics of citizenship through a series of direct and indirect encounters with other Americans. The first incident happens while overhearing the public outcry for military response over the radio. "ricardo," presumably a radio personality or interviewee in a news 
program, declares: "i will / feel so much better when the first bombs drop over there. and my / friends feel the same way" (Hammad). A second incident soon follows when a woman in a parked car fumes "'we're gonna burn them so bad, i swear, so bad" (Hammad). Both characters voice a version of patriotism that demonizes ArabAmericans and insists on the necessity of US military retaliation. These encounters have profound impacts on the Palestinian-American identity of the speaker. Taken aback, she feels a surge of conflicting emotions, such as her connection to the global struggle of her Palestinian brethren and a loyalty to her "friends and fam" at home (Hammad). This dynamism between the two cultural realties of the "i" portrays how reducing patriotism to a zero-sum game, in which the only possibilities are Palestinian or American, neglects the complexities of multicultural societies. It also bears light on the psycho-emotional repercussions of the rhetoric of patriotic expression.

One of the poem's greatest merits rests in its resistance to oversimplification. For example, at the end of section four, the poem demonstrates the complexities of national identity and love of country through the speaker's admission to having a brother in the Navy and being Arab. What follows is a touching, almost maternal moment, when a "big white woman" embraces the speaker to comfort her (Hammad). The reality that Arab-Americans protect America's boarders, citizens and political interests through their service in US military contrasts the stereotypes prevalent in journalism at the time. Such moments within the poetry affirm Rothberg's belief of the capacity for counterpublics to "challenge the supposed neutrality and transparency of the general public" (Rothberg, "Between Auschwitz and Algeria" 179). The speaker's reply "word" functions affirmatively, as in word up!, and perhaps interrogatively, as in what's the word for me? As Steven Salaita explains: "after 9/11 [Arab Americans] were faced with a demand to transmit or translate their culture to mainstream Americans" (149). Here, Hammad's poem resists pervasive patriotism by testifying to the multifaceted nature of American citizen responses. The scene is also unique in its ability to reexamine the stereotypes the " $\mathrm{i}$ " herself entertains. The speaker's shock from the embrace forces her to rethink the preconceptions of community, since any comfort is good comfort.

Hammad's poem exposes the capacity of transcultural counterwitnessing to challenge pervasive patriotism through its recognition of multidirectional remembrances. By establishing points of contact between other events, people, histories, and narratives of suffering, "First Writing Since" acknowledges how nations and their citizens make sense of historical events. For example, in section four, just following the speaker's encounter with the woman in a parked car who threatens military retaliation, the speaker conjoins $9 / 11$ with other historical spaces of violence:

[...] my hand went to my

head and my head went to the numbers within it of the dead Iraqi

children, the dead in nicaragua. the dead in rwanda who had to vie

with fake sport wrestling for america's attention. (Hammad)

Here, the poem overlaps with other sites of violence, such as America's involvement in the Gulf War and its freshly started War on Terror, with its support for the Nicaraguan contras in the 1980s, and its disinterest in the Rwandan genocide in the 1990s, to introduce the historico-political spaces of $9 / 11$. To reduce $9 / 11$ to a Muslim/Christian clash of civilizations is to turn a blind eye to its more complicated historical origins, such as in colonial and Cold War politics, and the dangers of militarized nationalism. The US government funded extremist groups throughout the 20th century to challenge 
Communism, fight enemies of the state, and strengthen its global reach, with many of these conflicts leading to regional instability and the rise of authoritarian regimes (McSherry 35-37, 208).

In some of the most telling moments of the poem, transcultural counterwitnessing helps stage the emotional struggle of the Arab female " $\mathrm{i}$ " in the face of public stigma. For example, section five presents one of the more explicit performances of the Arab, female " $i$ " with its sharp criticism of anti-Arab, pro-American, propaganda that views religion and ethnicity as key factors for determining citizenship (Fadda-Conrey 535). ${ }^{12}$ The speaker's retort urges readers to witness larger issues of unilateral suffering:

and when we talk about holy books and hooded men and death, why do we never mention the kkk?

if there are any people on earth who understand how new york is feeling right now, they are in the west bank and the gaza strip. (Hammad)

21 By positioning New York City in relation to the West Bank, Hammad's " $\mathrm{i}$ " challenges nationwide feelings of exclusive victimization. The contemporary reader might be reminded of photographs from the Second Intifada, while similarly thinking of the tragic images captured by Peter Morgan at Ground Zero, through Hammad's unlikely pairing of two devasted landscapes. Remembrance in the poetry functions multidirectionally, reminding readers that our relationship to the past is not straightforward, but full of unexpected connections that bind us to each other (Rothberg, Multidirectional Memory 12-13). It is no wonder that the speaker feels "less american and more new yorker" (Hammad). Consequently, readers are forced to confront their own agency in historical suffering. As the speaker reminds us, "[shit] is complicated" (Hammad), and even though it may be easier to reduce terror to victims and perpetrators, in real life, such reduction cannot hold.

The final section of "First Writing Since" returns the reader to the visual destruction at Ground Zero to reimagine the theme of global citizenship. The section opens with its most graphic description of the attack zone:

all day, across the river, the smell of burning rubber and limbs

floats through. the sirens have stopped now. the advertisers are

back on the air. the rescue workers are traumatized. the skyline is

brought back to human size. no longer taunting the gods with its

height. (Hammad)

On a primary level, the images provide poetic closure: the return "to human size" refocuses the poetry on the present realities. The aural and olfactory images reawaken the speaker from the abstract nightmare she has been caught in and bring her back to the immediacy of the moment. On a secondary level, the allusion to Babel draws attention to the dangers of Western hubris by visualizing the crumbling hope of globalization and multiculturalism. Babel metaphors have found new meanings in Western promises of borderless worlds and global citizenship (Green and Ruhleder 56). The Babel echo challenges the mistaken ethos of Western globalization, a civilization committed to global trade and limitless technological advances. The fall of the World Trade Center suggests the break-up of civilization, a civilization built on the unproven promises of cross-ethnic cooperation and economic prosperity.

Moreover, the Babel allusion addresses the imperial factors behind terror, as the falling towers reinforce how ambition is paid for in human collateral. Here, the speaker plays the role of transcultural counterwitness, a witness to extreme violence at and beyond 
national borders. I am not suggesting that Hammad wishes to denigrate internationalism or justify acts of terror; however, it can be claimed that Hammad aims to remind readers that the $9 / 11$ attacks were not only acts of madness, but calculated responses to larger issues of global inequality and injustice. The poem's complicated perspective, linking 9/11to violence around the globe, counters extremism by illuminating the complicated truths of terror while offering an alternative to overly simplistic forms of patriotism.

The primary message of "First Writing Since" is not about division. The final lines of the poem reaffirm Hammad's commitment to fight for justice and unity. By evoking the image of the phoenix, the speaker implies that just as the mythical bird takes new form from the ashes of its previous body, so must Americans find new meaning from the wasted landscape before them. In the poem's closing words, the speaker redefines the parameters of post $9 / 11$ citizenship by delivering one of the poem's most important themes: terrorism teaches us that life is more important than death. The repeated call to "affirm life" (Hammad) echoes like a battle call and urges all Americans to join in solidarity. The return to the performative "we" makes the transition from the individual to collective once again and reunites the othered " $\mathrm{i}$ " to the greater, mourning public. This study will now turn its attention to Martin Espada's "Alabanza" and his efforts to elegize those victims who were denied voices outright.

\section{Praising the Shadows in Martin Espada's "Alabanza"}

Martin Espada was "haunted" by an investigative report from the BBC about the undocumented workers who died while working at the Windows of the World restaurant at the World Trade Center ( $O^{\prime}$ Conner). During a reading at the College of Southern Maryland, Espada reflected on how "Alabanza" was a tribute to the "shadow army making those buildings run" who were "invisible in life and even more invisible in death" ("Martin Espada-Alabanza"). Published approximately a year after the attacks in The Nation, and then in his 2003 collection New and Selected Poems, the poem is a lyrical elegy, consisting of five stanzas, rich in image and varied in tempo. Espada's title (the Spanish word for "praise") takes the closing the lines of Juan Antonio Corretjer's "Oubao-Moin" ["Island of Blood"], from his collection Alabanza en la Torre de Ciales [Song of Praise from the Tower of Ciales]. ${ }^{13}$ For Espada, Corretjer's poem "envisioned a movement for a 'liberated homeland' that was not only working class, but multiracial, based on a shared history of labor and exploitation" ("The Lover of a Subversive Is Also a Subversive" 520). His use of allusion places the migrant workers at the center of a decisive moment in modern history to present the realities of American economic and political practices. This section progresses by first acknowledging the specific role of elegy for Espada's political messages before exploring the use of multidirectional remembrance to counterwitness the attacks.

Espada's commitment to elegize migrant workers should not be underestimated. Elegy, as a genre, serves specific literary and cultural purposes in collective mourning and celebrating of the dead. In the modern era, television and social media have transformed death and grieving into large public spectacles, encouraging viewers to participate in public loss (Kennedy 7). Narratives of victimization often serve as representations of national identity to characterize desired stories of statehood. Elegy, like other forms of memorialization, assumes a collective role in the formation of 
national identity, as recursive language and images foster a nationwide sense of community (Ramazani 76).

As noted, following the attacks some mainstream journalism emphasized narratives linking heroism and innocence to whiteness (Toh 2). Thus pervasive patriotism puts forth its own, nationalistic form of the elegy, which seeks to strengthen national identity through its connection of mourning and nationalism. Espada counters this through an elegiac transnationalism. Jahan Ramazani defines elegiac transnationalism as poetic elegy that "redirects poetic mourning across national borders, building affective microcommunities that instance the possibilities of a public sphere not contained and subsumed by the nation-state" (Ramazani 82). Espada's conscious choice to elegize the migrant workers in the World Trade Center highlights how poetry can challenge pervasive representations of the public sphere and draw attention to the difficulties of the global poor. His recital of "Alabanza" in spaces of national protest, for example at Amhurst College on May 1, 2006 during the National Boycott for Immigrant Rights $^{14}$, and its successful broadcast on channels like YouTube, offers a moving testimony of how elegy operates as witnessing for those who remain on the margins. Espada wanted his use of Spanish to sound "deliberately irregular" so that it would break with rhythmic expectations and draw recognition to the dead workers (O'Conner). Throughout the poem "Alabanza" is a declarative, given a full stop after each utterance, all but once. The polysyllabic, Spanish "Alabanza" is verbally dramatic, forcing emphasis on its multiple stresses and tonal variances: its affect is exaggerated further when juxtaposed against its monosyllabic, English counterpart "Praise." ${ }^{15}$ The aural qualities of the Spanish cast an ethereal musicality over the stanzas, while the frank English directs the reader to the subjects and actions performed. The bilingual variations dislocate the reader, delocalizing the dominant, English-speaking experience, to relocate the attacks cross-culturally and redirect mourning across national borders to recognize wider intercultural dynamics such as the role of geopolitics and global capitalism.

The poem also amasses a series of images to individualize the undocumented workers: it affords the workers unique personal pasts; this transforms dead objects into living subjects, making the invisible, visible. For example, the subtle detail of the Spanish "Oye," tattooed on the arm of the Puerto Rican cook, characterizes the subject, perhaps suggesting something about his brazenness, but also asks the reader to "listen" to his fate as well. Such details are important for the poem's counterwitness agenda because they challenge the damaging representations of pervasive patriotism which view migrants as physical, cultural and economic threats (Cisneros 572; Esses, Medianu and Lawson 522). By affording dignity to the migrant workers, the poem celebrates the numerous immigrant communities who contribute to American society and rebukes the political characterizations and scapegoating of immigrants, offering instead moments of human compassion and recognition for the dead workers. ${ }^{16}$

31 By bringing the migrant workers to the forefront of the attacks, Espada links American capitalists' exploitation of the global poor with the events of $9 / 11$. The speaker presents his criticism of global capitalism through the experience of the New York skyscape and the cultural imageries associated with its presence: ${ }^{17}$

Praise Manhattan from a hundred and seven flights up,

like Atlantis glimpsed through the windows of an ancient aquarium.

Praise the great windows where immigrants from the kitchen

could squint and almost see their world, hear the chant of nations: 
Ecuador, México, Republica Dominicana,

Haiti, Yemen, Ghana, Bangladesh. (Espada, “Alabanza” 231) captures the emotional claustrophobia of being stuck between worlds. To be trapped in an "aquarium" is to be trapped from the inside looking out. The visual distance of the squinting worker holds profound symbolism: from the migrant worker's perspective, the poem testifies to the effects of diaspora on displaced peoples who are trapped in a world far from their own; for the reader, the poem testifies to a more troubling reality, as the workers normally hidden are brought to light and given voices. Moreover, the countries listed by the speaker have documented histories of human rights abuses, mass exoduses, and troubling, political-economic relationships with The United States of America. The interchangeableness between countries bears light on America's responsibility in the production of global migrations. In this context, "Alabanza," like other works of politically motivated literature, asks its audience to consider how the relationship between people and the material world moves beyond passive consumption by recognizing how industrialized countries profit from unprocessed traumas of the economic and political pasts (Mengal and Borzaga, ix-xi).

Espada also conjoins the trauma of $9 / 11$ with other distant histories, further demonstrating transcultural poetry's capacity to bring forth unexpected encounters through multidirectional remembrances. For example, when referencing "the cook's yellow Pirates cap / worn in the name of Roberto Clemente" (231), the poem entangles the tragic fate of cook with the tragic fate of the baseball icon. Clemente's death is well documented. On December 31, 1972, Clemente chartered a plane to bring relief supplies to survivors of an earthquake in Nicaragua. The plane crashed off the coast of Puerto Rico due to a faulty engine and overstocked cargo. While the crash has become something of a sports legend, most Americans fail to acknowledge that Clemente was on the flight due to the mass corruption of the Somoza regime, as his previous relief efforts, which included medical aid and an x-ray machine, never reached the people he intended to help (Fisher; Davidson Sorkin). The links between the United States and Anastasio "Tachito" Somoza are extensive. Not only was he educated in the United States and graduated from the esteemed West Point Academy, but even more troubling is that the United States supported Somoza's National Guard and assisted his rise to power (Katovich 23-27). Following his coup in 1937, Anastasio Somazo installed a government ripe with corruption and amassed one of the largest fortunes in the region ("The Somazo Era"). Read in this historico-political context, the poem opens up for a transcultural reading and can be seen to grieve for the undocumented workers in a way that situates $9 / 11$ in relation to a variety of international conflicts, including those abetted by US involvement in Central America. The allusion illustrates how transcultural counterwitnessing uses multidirectional remembrance to bring traumatic pasts into contact and thus remind readers of the "unexpected or even unwanted consequences that bind us to those whom we consider other" (Multidirectional Memory 13). Among these are the geopolitical factors contributing to migration. Consequently, the poem forces its reader to ponder unexpected ethical questions such as How do the political actions of America's past affect the traumatic realities of others? and Do these traumas deserve recognition?

These questions are potentially addressed through the final stanzas. Like Hammad, Espada draws on babelesque images to visualize the collapse of the towers and comment on perils of the global poor. Violent images of wild thunder and blinding 
light, and unsettling seconds of silence, evoke a "Wrath of God" moment where "the smoke-beings flung in constellations / across the night sky" warn the readers of "this city and cities to come" ("Alabanza" 232). The image of smoke drifting from Manhattan towards Kabul conjoins two attack zones, making the migrant-workers and Afghan victims' experiences interchangeable. Here, readers are also reminded of other countries affected by US and NATO military responses to $9 / 11$, for example Iraq, Libya, and Syria. Such moments in the poetry confirm Espada's ability to "realize the multidirectional interconnectedness of all human experience in space and time" (Salgado 208). The poem's final dialogue raises numerous potential associations as well. The "song and dance" metaphor could allude to the banning of music in Afghanistan under the Taliban regime. Music had long been associated with celebration and freedom in Afghanistan but became symbolic for a functional society after Taliban rule, as it signaled a return to normal life (Bailey 24; Wroe). But the poetry refuses celebration. Although the Spanish and Afghan exchange is a moment of transcultural dialogue between East and West, the tone is not uplifting but something more defeatist, perhaps questioning the larger geo-political and economic structures in place. In the end, life does not change, and "the same old song and dance" continues for the global poor.

\section{Conclusion}

The poems by Suheir Hammad and Martin Espada demonstrate how transcultural counterwitnessing activates alternate perspectives to challenge the pervasive patriotism of mainstream media. Through their use of multiple perspectives, voices, and memories, transcultural counterwitnesses demonstrate how pervasive patriotism often confers ethical and moral privilege to dominant, cultural groups. Such performances also reveal the complex realities of marginal groups in diverse societies, such as the United States. The readers of the poems are invited to reconsider how pervasive patriotism limits broader discussions of national and global identity. By encouraging readers to witness the attacks from other perspectives, transcultural counterwitnessing acknowledges the multifaceted realties of terror for multicultural societies and draws attention to how a multidirectional consciousness promotes diversity in public discourses.

Secondly, transcultural counterwitnessing reminds readers how sites of violence, like 9/11, become entangled in larger networks of cultural, political, and social realities. Transcultural counterwitnessing compels readers to acknowledge how national foreign policies, economic practices, and military actions, collide into, and ricochet off, other events.

Lastly, if poetry should ask questions, as Hammad insisted in her interview with Mary Knopf-Newman (91), then the two poems under investigation provide numerous questions about the significance of $9 / 11$, both past and present. Historical trauma has lasting effects on how one imagines claims of national and global identity. Transcultural accounts, such as those addressed in the study, illustrate how 9/11 established a foundation for reassessing what it means to witness historical events, with art and literature providing spaces that go beyond the boundaries of patriotism. As Michael Rothberg notes in his 2009 article "A Failure of Imagination," literature about 9/11 helps readers "imagine how US citizenship looks and feels beyond the 
boundaries of the nation-state, both for Americans and for others" (158). In times of polarized politics, 9/11 must remain a site of empathetic imagination, as testified in the poetry analyzed in this essay.

\section{BIBLIOGRAPHY}

Anker, Elisabeth. "Villains, Victims and Heroes: Melodrama, Media, and September 11." Journal of Communication 55.1 (March 2005): 22-37. Print. DOI: 10.1111/j.1460-2466.2005.tb02656.x

Azank, Natasha. "A Poetry Like Ammunition: Martin Espada's Poetics of Resistance and Subversion." Acknowledged Legislator: Critical Essays on the Poetry of Martín Espada. Ed. Edward J. Carvalho. Madison: Fairleigh Dickinson University Press, 2014. 133-155. eBook Collection (EBSCOhost). Web. Dec 2019.

Baily, John. "Music Censorship in Afghanistan Before and After the Taliban." Shoot the Singer. Ed. Marie Korpe. London: Zed Books, 2004. 19-28. Google Books. Web. 3 April 2019.

Bauridl, Birgit M. "Rowing for Palestine," Performing the Other: Suheir Hammad, Mark Gerban and Multiple Consciousness." Journal of Transnational American Studies 5.1 (2013): 221-242. Web. 2 Dec 2018.

Bird, Elizabeth S. “Taking It Personally: Supermarket Tabloids After September 11." Journalism After September 11. Eds. Barbie Zelizer and Stuart Allan. New York: Routledge, 2004. 141-159. Print. 27 August 2019.

Blake, Angela M. How New York Became American, 1890-1924. Baltimore: Johns Hopkins University Press, 2006. eBook Collection (EBSCOhost). Web 14 March 2019.

Brooker, Peter. New York Fictions: Modernity, Postmodernism, The New Modern. London: Longman, 1996. Print.

Baudrillard, Jean. The Spirit of Terrorism. New rev. ed. Trans. Christ Turner. London: Verso, 2003. Print.

Billig, Michael. Banal Nationalism. London: Sage, 1995. Print.

Carvalho, Edward J. “Taking Back the Street Corner: Interview with Martin Espada.” Works and Days 51/52, 53/54. 26 \&27 (2008-09): 539- 550. Web. 5 Dec 2019.

Clark, J. Elizabeth. “Versus Verse: Poets Against War.” The Radical Teacher 74 (2005): 6-11. Web. 12 August 2019.

Cisneros, J. David. “Contaminated Communities: The Metaphor of 'Immigrant as Pollutant' in Media Representations of Immigration.” Rhetoric \& Public Affairs 11.4 (Winter 2008): 569-601. Print. DOI: 10.1353/rap.0.0068

Davidson Sorkin, Amy. “Close Read: Clemente and the Earthquake." The New Yorker, 14 Jan 2010. Web. 14 Aug 2018.

Dean, Carolyn J. The Moral Witness: Trials and Testimony After Genocide. New York: Cornell University Press, 2019. eBook Collection (EBSCOhost). Web. 26 Aug 2019. 
Du Bois, W. E. B., and Brent Hayes Edwards. The Souls of Black Folk. Oxford: Oxford University Press, 2007. eBook Collection (EBSCOhost). Web. 17 Sept 2019.

Espada, Martin. “Alabanza: In Praise of the Local 100." Alabanza: New and Selected Poems 1982-2002. New York: WW Norton \& Company, 2004. Print.

-. "The Lover of a Subversive is Also a Subversive: Colonialism and the Poetry of Rebellion in Puerto Rico." Massachusetts Review 51.3 (2010): 510-529. Web. 27 Nov 2019.

Esses, Victoria M., Stelian Medianu, and Andrea S. Lawson. "Uncertainty, Threat, and the Role of the Media in Promoting the Dehumanization of Immigrants and Refugees." Journal of Social Issues 69.3 (Sept. 2013): 518-536. Print. DOI:10.1111/josi.12027

Fadda-Conrey, Carol. "Arab American Citizenship in Crisis: Destabilizing Representations of Arabs and Muslims in the US after 9/11." MFS: Modern Fiction Studies 57.3 (2011): 532-555. Print. DOI: $10.1353 / \mathrm{mfs} .2011 .0068$

Fisher, James T. "Pirate of the Caribbean." Commonweal, 16 Oct 2006. Web. 26 Apr 2018.

Fraser, Nancy. "Rethinking the Public Sphere: A Contribution to the Critique of Actually Existing Democracy." Social Text 25/26 (1990): 56-80. Web. 1 August 2019.

Gershkoff, Amy, and Shana Kushner. "Shaping Public Opinion: The 9/11-Iraq Connection in the Bush Administration's Rhetoric.” Perspectives on Politics 3.3 (2005): 525-537. Print. DOI: 10.1017/ S1537592705050334

Gray, Jeffrey. "Precocious Testimony: Poetry and the Uncommemorable." Literature After 9/11. Eds. Ann Keniston and Jeanne Follansbee Quin. New York: Routledge, 2008. 261-284. Print.

Green, Carolyn, and Karen Ruhleder. "Globalization, Borderless Worlds, and the Tower of Babel: Metaphors Gone Awry." Journal of Organizational Change Management 8.4 (1995): 55-68. Print. DOI: 10.1108/09534819510090213

Gustafson, Sandra M. “American Literature and the Public Sphere.” American Literary History 20.3 (2008): 465-478. Print.

Hammad, Suheir. "First Writing Since (Poem on Crisis of Terror)." Inmotionmagazine.com. 7 Nov 2001. Web. 15 Oct 2017.

Harb, Sirène. "Naming Oppressions, Representing Empowerment: June Jordan's and Suheir Hammad's Poetic Projects.” Feminist Formations 26.3 (Winter 2014): 71-99. Print. DOI: 10.1353/ff. 2014.0035

Hauptman, Samantha. The Criminalization of Immigration: The Post 9/11 Moral Panic. El Paso: LFB Scholarly Publishing LLC, 2013. eBook Collection (EBSCOhost). Web. 22 Nov 2019.

Hopkinson, Natalie. "Out of the Ashes, Drops of Meaning: The Poetic Success of Suheir Hammad." The Washington Post 13 Oct 2003. Rpt. in The Electronic Intifada. Web. 12 Jan 2019.

Jamieson, Kathleen Hall, and Paul Waldman. The Press Effect: Politicians, Journalists, and The Stories That Shape The Political World. Oxford: Oxford University Press, 2004. Web. 14 Sept 2019.

Jegić, Denijal. "Breaking Dichotomies: Counter-Narratives in the Spoken Word Poetry of Suheir Hammad." Current Objectives of Postgraduate American Studies 15.1 (2015): 1-23. Web. 19 Dec 2019. DOI: $10.5283 /$ copas.227

Jenks, Charles. "Martin Espada Recites Alabanza: In Praise of Local 100.” Youtube, 23 Nov 2006. Web. 28 Mar 2019. 
Johnson, Dennis Loy, and Valerie Merians. "Foreword." Poetry After 9/11: An Anthology of New York Poets. Eds. Dennis Loy Johnson and Valerie Merians. New York: Melville House Publishing, 2011. Google Books. Web. 14 Apr 2019.

Katovich, Kevin A. "Human Rights and Policy Wrongs: United States Involvement in the Creation and Overthrow of the Somoza Regime." Digital Honors Projects, 29 (1993): 1-59. Web. 23 Aug 2018.

Keniston, Ann. “'Not Needed, Except as Meaning': Belatedness in Post-9/11 American Poetry." Contemporary Literature 52.4 (Winter 2011): 658-683. Print. DOI: 10.1353/cli.2011.0043

Kennedy, David. Elegy. New York: Routledge, 2007. Print.

Knopf-Newman, Marcy Jane. “Interview with Suheir Hammad.” MELUS 31.4 (2006): 71-91. Print. DOI: $10.1093 /$ melus/31.4.71

Li, Qiong, and Marilynn B. Brewer. "What Does It Mean to Be an American? Patriotism, Nationalism, and American Identity After 9/11." Political Psychology 25.5 (Oct 2004): 727-739. Print. DOI: 10.1111/j.1467-9221.2004.00395.x

Lindner, Christoph. "New York Undead: Globalization, Landscape Urbanism, and the Afterlife of the Twin Towers." The Journal of American Culture 31:3 (2008): 302-314. Print. DOI: 10.1111/j. 1542-734X.2008.00678.X

"Martin Espada-Alabanza." Connections Literary Series College of Southern Maryland. YouTube, 2 Nov 2007. Web. 15 March 2019.

McSherry, J. Patrice. Predatory States: Operation Condor and Covert War in Latin America. Lanham, MD: Rowman \& Littlefield Publishers, 2005. eBook Collection (EBSCOhost). Web. 24 Feb 2020.

Mengel, Ewald, and Michela Borzaga. "Introduction." Trauma, Memory, and Narrative in the Contemporary South African Novel: Essays. Amsterdam: Brill/Rodopi, 2012. vii-xxxi. eBook Collection (EBSCOhost). Web. 15 Mar 2019.

Metres, Philip. "Beyond Grief and Grievance: The Poetry of 9/11 and its Aftermath." The Poetry Foundation, 7 Sep 2011. Web. 15 Apr 2018.

O'Connor, John. "An Interview with Martin Espada: On 9/11 and the Politics of Language." Solidarity, September/October 2011. Web. 11 May 2018.

Perez-Bustillo, Camilo. "Heart of Hunger: Martin Espada and the Poetry of Liberation." Acknowledged Legislator: Critical Essays on the Poetry of Martín Espada. Ed. Edward J. Carvalho. Madison: Fairleigh Dickinson University Press, 2014. 159-217. eBook Collection (EBSCOhost). Web. 5 Dec 2019.

Powell, Kimberly A. "Framing Islam: An Analysis of US Media Coverage of Terrorism Since 9/11." Communication Studies 62.1 (2011): 90-112. Print. DOI: 10.1080/10510974.2011.533599

Ramazani, Jahan. A Transnational Poetics. Chicago: University of Chicago Press, 2009. eBook Collection (EBSCOhost). Web. 12 Dec. 2018.

Roberts, David. Global Governance and Biopolitics: Regulating Human Security. London: Zed Books, 2010. eBook Collection (EBSCOhost). Web. 28 June 2019.

Rothberg, Michael. "A Dialogue on the Ethics and Politics of Transcultural Memory.” With A. Dirk Moses. The Transcultural Turn: Interrogating Memory Between and Beyond Borders. Ed. Lucy Bond and Jessica Rapson. Berlin: De Gruyter (2014): 29-38. Print.

-. "A Failure of the Imagination: Diagnosing the Post-9/11 Novel: A Response to Richard Gray." American Literary History 21. 1 (Spring 2009): 152-158. Print. DOI: 10.1093/alh/ajn040 
-. "Between Auschwitz and Algeria: Multidirectional Memory and the Counterpublic Witness." Critical Inquiry 33.1 (2006): 158-184. Print. DOI: 10.1086/509750.

-. Multidirectional Memory: Remembering the Holocaust in the Age of Decolonization. Stanford: Stanford University Press, 2009. eBook Collection (EBSCOhost). Web. 13 Jan 2018.

-. "Seeing Terror, Feeling Art: Public and Private Post 9/11 Literature." Literature After 9/11. Eds. Ann Keniston and Jeanne Follansbee Quinn. New York: Routledge, 2008. 123-142. Print.

-. "Writing Ruins: The Anachronistic Aesthetics of André Schwarz-Bart." After Representation?: The Holocaust, Literature, and Culture. Eds. Robert Ehrenreich and R. Clifton Spargo. New Brunswick: Rutgers University Press and US Holocaust Memorial Museum, 2009. 99-118. eBook Collection (EBSCOhost). Web. 2 July 2019.

Rutenberg, Jim. "Fox Portrays a War of Good and Evil, and Many Applaud." The New York Times, 3 Dec 2001. Web. 14 Aug 2019.

Salgado, César A. “About Martin Espada.” Ploughshares 31:1 (Spring 2005): 203-208. Web. 12 Dec 2019.

Salaita, Steven. "Ethnic Identity and Imperative Patriotism: Arab Americans Before and After 9/11." College Literature 32:2 (Spring 2005): 146-168. Print. DOI: 10.1353/lit.2005.0033

"The Somoza Era, 1936-74." Nicaragua: A Country Study. Ed. Tim Merrill. countrystudies.us. Library of Congress (1994). Web. 23 Aug 2018.

Toh, Justine. "The White Fireman and the American Heartland in the Memory of 9/11." Australian Critical Race and Whiteness Studies Association ejournal 6.1 (2010): 1-17. Web. 27 Mar 2019. Waisbord, Silvio. “Journalism, Risk, and Patriotism.” Journalism After September 11. Eds. Barbie Zelizer and Stuart Allan. New York: Routledge, 2004. 201-219. Print.

Warner, Michael. "Publics and Counterpublics." Public Culture 14.1 (Winter 2002): 49-90. Print. Wolf, Werner. "The Lyric: Problems of Definition and a Proposal for Reconceptualisation." Theory Into Poetry: New Approaches to the Lyric. Eds. Eva Müller-Zettelmann and Margarete Rubik. Amsterdam: Brill Academic Publishers, 2005. 21-56. eBook Collection (EBSCOhost). Web. 17 Apr 2019.

Wroe, Nicholas. “A Muted Culture.” The Guardian, 13 Oct 2001. Web. 3 Apr 2019.

Zelizer, Barbie and Stuart Allan. "Introduction: When Trauma Shapes the News." Journalism After September 11. Eds. Barbie Zelizer and Stuart Allan. New York, Routledge, 2004. 1-24. Print.

Zamorano Llena, Carmen. "Transnational Movements and the Limits of Citizenship Redefinitions of National Belonging in Joseph O'Neill's Netherland.” Transcultural Identities in Contemporary Literature. Eds. Zarmorano Llena, Hansen, and Nordin. Amsterdam: Brill | Rodopi, 2013. 3-24. eBook Collection (EBSCOhost). Web. 25 November 2019.

Zamorano Llena, Carmen, Julie Hansen, and Irene Gilsenan Nordin. "Introduction: Conceptualizing Transculturality in Literature." Transcultural Identities in Contemporary Literature. Eds. Zarmorano Llena, Hansen, and Nordin. Amsterdam: Brill | Rodopi, 2013. ix-xxvii. eBook Collection (EBSCOhost). Web. 25 November 2019. 


\section{NOTES}

1. This was best exemplified when Copper Canyon Press editor and poet Sam Hamill invited amateur and professional poets to protest Laura Bush's planned Poetry and the American Voice seminar in opposition of the Bush administration's War in Iraq. By February 2003, Hamill received over 13,000 poems on his website Poets Against War. The poems were compiled in print and presented to Congress on 5 March 2003. Martin Espada's "Alabanza" was part of this collection. For a very comprehensive summary of the movement see Clark, J. Elizabeth. "Versus Verse: Poets Against War." The Radical Teacher 74 (2005): 6-11. Print.

2. For this context, "nationalism" refers to the everyday representations of nation that contribute to one's sense of belonging. See Billig, Michael. Banal Nationalism. London: Sage, 1995. Print.

3. "Portraits of Grief" was a series of elegies for the victims of 9/11. It began around three days after the attacks when a group of reporters at The New York Times started to interview friends and relatives of the missing and dead.

4. "American Muslim Community Since September 11" was a PBS special which aired in October 2001. In the documentary, journalist Ray Suarez examines how life changed for Muslim Americans after the 9/11 attacks.

5. Hauptman identifies this media phenomenon as a form of "informal social control" (127) where media identifies foreign born people as "folk devils." In her book she details how media uses scapegoating to target immigrants and non-citizens as "the other" who pose immediate threats to American society. See Hauptman, Samantha. The Criminalization of Immigration: The Post 9/11 Moral Panic. El Paso: LFB Scholarly Publishing LLC, 2013. Web. 22 Nov 2019.

6. This quote is taken from David Roberts' work Global Governance and Biopolitics: Regulating Human Security. Although Roberts is not concerned with poetry, his idea resonates with the poets' themes and this paper's interest. See Roberts, David. Global Governance and Biopolitics: Regulating Human Security. London: Zed Books, 2010. eBook Collection (EBSCOhost). Web. 28 June 2019.

7. See Bauridl, Birgit M. "“Rowing for Palestine," Performing the Other: Suheir Hammad, Mark Gerban and Multiple Consciousness." Journal of Transnational American Studies, 5.1 (2013): 221-242. Web. 2 Dec 2018; and Jegić, Denijal. "Breaking Dichotomies: Counter-Narratives in the Spoken Word Poetry of Suheir Hammad." Current Objectives of Postgraduate American Studies, 15.1 (2015): 1-23. Web. 12 Dec 2018. DOI: 10.5283/copas.227.

8. See Rothberg, Michael. "Seeing Terror, Feeling Art: Public and Private Post 9/11 Literature." Literature After 9/11. Eds. Ann Keniston and Jeanne Follansbee Quinn. New York: Routledge, 2008. 123-142. Print.

9. The Amber Alert is a child abduction messaging system used in all 50 states. It was designed to be an early warning system to inform communities of missing children. Once law officials determine that a child is missing, the system interrupts TV and radio programming to broadcast that an abduction has occurred. The alert can also be transmitted via digital billboards, wireless devices, and Internet Service Providers.

10. This study uses Werner Wolf's definitions of self-referentiality and self-reflexivity in this context. See Wolf, Werner. "The Lyric: Problems of Definition and a Proposal for Reconceptualisation." Theory Into Poetry: New Approaches to the Lyric. Eds. Eva Müller-Zettelmann and Margarete Rubik. Amsterdam: Brill Academic Publishers (2005): 21-56. eBook Collection (EBSCOhost). Web. 17 Apr 2019.

11. This conflict describes the process where people of color see themselves through the white racialized gaze. See Du Bois, W. E. B., and Brent Hayes Edwards. The Souls of Black Folk. Oxford: Oxford University Press, 2007. eBook Collection (EBSCOhost). Web. 17 Sept 2019.

12. Fadda-Conrey's essay focuses on the depiction of Arab-Americans in post-9/11 fiction. She argues that literature forges spaces to redefine exclusionary concepts of citizenship by 
responding to "simplistic types" of post-911 patriotism, a concept closely related to "pervasive patriotism." See Fadda-Conrey, Carol. "Arab American Citizenship in Crisis: Destabilizing Representations of Arabs and Muslims in the US after 9/11." MFS: Modern Fiction Studies 57.3 (2011): 532-555. Print. DOI: 10.1353/mfs.2011.0068

13. Literary critic Camilo Pérez-Bustillo provides valuable insight to the social and cultural significance of Corretjer's poem. In his essay, Perez-Bustillo details how Corretjer's poem has been recited as song and reworked into theater and dance performances by Puerto Rican communities on the island. See Perez-Bustillo, Camilo. "Heart of Hunger: Martin Espada and the Poetry of Liberation." Acknowledged Legislator: Critical Essays on the Poetry of Martín Espada. Ed. Edward J. Carvalho. Madison: Fairleigh Dickinson University Press, 2014. 159-217. eBook Collection (EBSCOhost). Web. 5 Dec 2019.

14. "A Day Without Immigrants" was a one-day boycott of United States schools and businesses by immigrants in the United States on May 1, 2006. To view Espada's recital see Jenks, Charles. "Martin Espada Recites Alabanza: In Praise of Local 100." Youtube, 23 Nov 2006. Web. 28 Mar 2019.

15. In a reading at College of Southern Maryland, Martin Espada demonstrates its rhythmic effects through his dramatic reading of the poem. See "Martin Espada-Alabanza." Connections Literary Series College of Southern Maryland. YouTube, 2 Nov 2007. Web. 15 Mar 2019.

16. Other critics have written about such motifs in Espada's poetry. Two excellent works to reference are Azank, Natasha. "A Poetry Like Ammunition: Martin Espada's Poetics of Resistance and Subversion." Acknowledged Legislator: Critical Essays on the Poetry of Martín Espada. Ed. Edward J. Carvalho. Madison: Fairleigh Dickinson University Press, 2014. 133-155. eBook Collection (EBSCOhost). Web. 5 Dec 2019; and Carvalho, Edward J. "Taking Back the Street Corner: Interview with Martin Espada." Works and Days 51/52, 53/54. 26 \&27 (2008-09): 539- 550. Web. 5 Dec 2019.

17. Historically, New York City built its place in the global imagination by defining the modern skyscape through its relationship with economic prosperity, free market capitalism, and global modernization. From its early stages, the New York skyline hyperbolized the potentialities of the modern world. Important sites, such the Empire State Building, the Brooklyn Bridge, and the Statue of Liberty, "have vicariously connoted modernity, novelty, commercial power, technical knowhow, and political freedom" (Blake 11). By the mid-1920s, for example, New York City's cultural, economic and political dominance made it the "de facto capital of the United States" (Blake 5) and transformed the city into an important place of urban and national identification (Brooker 30). The World Trade Center provides an important space to further such cultural imaginaries. From its beginnings, the World Trade Center represented globalization in the modern age as well as the cultural and ethnic heterogeneity which accompanies it (Lindner 306). Through its network of global banking, stock exchanges, and trading firms, the World Trade Center solidified New York City's evolution as a global city (Boyer 53). Cultural theorist Jean Baudrillard describes how the violence of the attacks therefore epitomized a violent "protest" against the system it embodied (41). See Blake, Angela M. How New York Became American, 18901924. Baltimore: Johns Hopkins University Press, 2006. eBook Collection (EBSCOhost). Web. 14 March 2019; Brooker, Peter. New York Fictions: Modernity, Postmodernism, The New Modern. London: Longman, 1996. Print; Baudrillard, Jean. The Spirit of Terrorism. New rev. ed. Trans. Christ Turner. London: Verso, 2003. Print; and Lindner, Christoph. "New York Undead: Globalization, Landscape Urbanism, and the Afterlife of the Twin Towers." The Journal of American Culture 31:3 (2008): 302-314. Print. DOI: 10.1111/j.1542-734X.2008.00678.x 


\section{ABSTRACTS}

By drawing on current definitions of testimonial witnessing, this study returns to the attacks of September 11th to explore how two 9/11 poems, "First Writing Since (Poem on Crisis of Terror)" by Suheir Hammad and "Alabanza: In Praise of the Local 100" by Martin Espada, challenge the pervasive patriotism of mainstream journalism through acts of transcultural counterwitnessing. I explore how these $9 / 11$ poems oppose, and engage with, pervasive patriotism, and emphasize the value of transcultural poetry in the face of extreme violence. The notion of the transcultural counterwitness has the potential to redefine how third-party witnesses, like poets, provide new understandings of historical responsibility and national identity in the American imagination.

\section{INDEX}

Keywords: 9/11 Poetry, Counterpublic, Counterwitness, Multidirectional Memory, Transculturalism 